EVALUASI, 4 (1), Maret 2020, ISSN 2580-3387 (print) |

ISSN 2615-2886 (online)

Homepage : http://e-journal.staima-alhikam.ac.id/index.php/evaluasi

DOI : : http://doi.org/10.32478/evaluasi.v4i1.355

Article type : Original Reseacrh Article

\title{
REVITALISASI KEPEMIMPINAN KOLEKTIF-KOLEGIAL DALAM MEMBANGUN EFEKTIFITAS KOMUNIKASI ORGANISASI PESANTREN (STUDI INTERAKSIONISME SIMBOLIK DI PONDOK PESANTREN JOMBANG)
}

\section{Devi Pramitha \\ UIN Maulana Malik Ibrahim Malang}

\begin{abstract}
Nowadays, the leadership of Islamic Boarding School is no longer apply single leadership, and the organization of Islamic Boarding School has been included in the form of foundation. With this new phenomenon, the organization of Islamic Boarding School leads impersonally, without reducing the role of kiai as the supreme leader, then leadership leads to a collective pattern, in accordance with the hierarchy of leadership of a foundation organization. In this study there are two problems to be studied, namely: (1) collective-collegial leadership behavior; And (2) Model of organizational communication viewed from the theory of symbolic interactionism; In PP Bahrul Ulum Tambakberas and PP Mambaul Maarif Denanyar Jombang. This research uses qualitative research approach and the type of research is phenomenology by using symbolic interaction design. Data obtained by interview (interview), documents (document) and observation (observation). Data analysis using Spradley model which take one of the analysis that is domain analysis. There are two findings obtained, namely, First, collective-collegial leadership behavior in PPBU Tambakberas Jombang are: (1) participatory-democratic, while in PPMA Denanyar Jombang is (2) participative-consultative. Secondly, there are two models of organizational communication
\end{abstract}

Email: devipramitha@uin-malang.ac.id

EVALUASI: Jurnal Manajemen Pendidikan Islam is licensed under

The CC BY License (https://creativecommons.org/licenses/by-sa/4.0/) 
EVALUASI, 4 (1), Maret 2020, ISSN 2580-3387 (print) |

ISSN 2615-2886 (online)

Homepage : http://e-journal.staima-alhikam.ac.id/index.php/evaluasi

DOI : : http://doi.org/10.32478/evaluasi.v4i1.355

Article type : Original Reseacrh Article

applied both in PPBU Tambakberas Jombang and PPMA Denanyar Jombang are "top-down" communication and "buttomup" communication.

Keyword: Leadership, Collective-Collegial, Organizatioanal Communication

\section{ABSTRAK}

Dewasa ini kepemimpinan pesantren yang terjadi tidak lagi menerapkan kepemimpinan tunggal, dan organisasi pesantren pun telah dimasukkan dalam bentuk yayasan. Dengan gejala baru ini, maka organisasi pesantren menjurus kearah impersonal, tanpa mengurangi peranan kiai sebagai pemimpin tertinggi, maka kepemimpinan mengarah pada pola kolektif, sesuai dengan hierarkhi kepemimpinan sebuah organisasi yayasan. Dalam penelitian ini ada dua masalah yang ingin diteliti, yaitu: (1) perilaku kepemimpinan kolektif-kolegial; dan (2) Model komunikasi organisasi pesantren ditinjau dari teori interaksionisme simbolik; di PP Bahrul Ulum Tambakberas dan PP Mambaul Maarif Denanyar Jombang. Penelitian ini menggunakan pendekatan penelitian kualitatif dan jenis penelitiannya adalah fenomenologi dengan menggunakan rancangan interaksionisme simbolik. Data diperoleh dengan wawancara (interview), dokumen-dokumen (documents) dan observasi (observation). Analisis data menggunakan model Spradley yang mengambil salah satu dari analisis yaitu analisis domain. Ada dua hasil temuan yang diperoleh, yaitu, Pertama, perilaku kepemimpinan kolektif-kolegial di PPBU Tambakberas Jombang adalah: (1) partisipatif-demokratis, sedangkan di PPMA Denanyar Jombang adalah (2) partisipatif-konsultatif. Kedua, Ada dua model komunikasi organisasi yang diterapkan baik di PPBU Tambakberas Jombang maupun di PPMA Denanyar Jombang yaitu, Komunikasi yang bersifat "top-down" dan komunikasi yang bersifat "buttom-up". 
EVALUASI, 4 (1), Maret 2020, ISSN 2580-3387 (print) |

ISSN 2615-2886 (online)

Homepage : http://e-journal.staima-alhikam.ac.id/index.php/evaluasi

DOI : : http://doi.org/10.32478/evaluasi.v4i1.355

Article type : Original Reseacrh Article

\section{Kata Kunci: Kepemimpinan, Kolektif-Kolegial, Komunikasi Organisasi PENDAHULUAN}

Membicarakan masalah kepemimpinan memang tidak akan pernah habisnya bahkan masih tetap saja menarik untuk dibahas dan diteliti. Hal tersebut karena kepemimpinan dapat dilihat dari sisi manapun seseorang memandang dan mengulas masalah tersebut dalam suatu objek kajian. Bila kepemimpinan dikaji dalam perspektif politik maka akan melahirkan pandangan yang berbeda bila dikaji dalam perspektif ekonomi, begitu pula jika dikaji dalam perspektif sosial. Oleh karena itu, pada setiap organisasi diperlukan sosok pemimpin yang memiliki kredibilitas dan kapabilitas dalam hal kepemimpinan.

Salah satu organisasi pendidikan yang besar adalah Pondok pesantren yang merupakan lembaga pendidikan Islam yang unik, tidak saja karena keberadaannya yang sudah sangat lama, tetapi juga karena kultur, metode dan jaringan yang diterapkan oleh lembaga agama tersebut berbeda dengan lembaga pendidikan Islam lainnya. Peranan pondok pesantren sendiri di Indonesia cukup besar dalam membangun masyarakat, hal ini dapat dilihat betapa besar kiprah dunia pesantren dalam mempertahankan bangsa dan Negara dari tangan penjajah selama berabad-abad yang kemudian berpuncak pada fatwa "Resolusi Jihad" pada Oktober 1945 yang dikeluarkan oleh KH. Hasyim Asy'ari pendiri PP. Tebuireng Jombang dan juga pendiri organisasi masyarakat terbesar Islam yakni, Nahdlatul 'Ulama (NU). Besarnya peran yang dimainkan oleh pondok pesantren tersebut bukan suatu kebetulan, tetapi ada nilainilai yang mendasarinya. Owens mengatakan dimensi soft yang berpengaruh terhadap kinerja individu dan organisasi, yaitu nilai-nilai (values), keyakinan (beliefs), budaya (culture), dan norma perilaku. ${ }^{1}$

Besarnya peranan pesantren tentu tidak lepas dari kepemimpinan kiai di pesantren tersebut. Sebagai sosok pemimpin central di pondok pesantren, Kiai juga memiliki tanggung jawab dalam menjaga komunikasi organisasi. Karena setiap manusia di dalam 2003), hlm. 81

1 Stephen P. Robbins, Organizational Behavior, (Mexico: Pentice Hall, 
EVALUASI, 4 (1), Maret 2020, ISSN 2580-3387 (print) |

ISSN 2615-2886 (online)

Homepage : http://e-journal.staima-alhikam.ac.id/index.php/evaluasi

DOI : : http://doi.org/10.32478/evaluasi.v4i1.355

Article type : Original Reseacrh Article

kehidupannya memerlukan berkomuikasi maka sebagian besar pribadi manusia terbentuk dari hasil integrasi sosial dengan sesama dalam kelompok dan masyarakat. Di dalam organisasi itu sendiri selalu terdapat bentuk kepemimpinan yang merupakan masalah penting untuk kelangsungan hidup organisasi, yang terdiri dari pemimpin dan bawahan/ karyawan. Di antara kedua belah pihak harus ada two way communications atau komunikasi dua arah atau komunikasi timbal balik, untuk itu diperlukan adanya kerja sama yang diharapkan untuk mencapai cita-cita, baik cita-cita pribadi maupun cita-cita organisasi

Survey yang dilakukan Universitas Michigan (1990), Pennsylvania State University dan Wake Forest University (1991) mendokumentasikan pentingnya keterampilan berkomunikasi untuk mencapai sukses organisasional. Dalam survey ini ditemukan 83,5\% jawaban mengatakan bahwa keterampilan komunikasi lisan dan tertulis menjadi salah satu faktor untuk mencapai kesuksesan organisasi. ${ }^{2} \mathrm{Hal}$ ini membuktikan bahwa komunikasi memegang peranan penting dalam organisasi. Tanpa komunikasi organisasi akan "mandek" (berhenti), karena tidaka ada dinamika yang berjalan dalam organisasi itu.

Chester Barnard mengatakan bahwa "setiap teori organisasi yang tuntas, komunikasi akan menduduki suatu tempat yang utama, karena susunan, keluasan dan cakupan organisasi secara keseluruhannya ditentukan oleh teknik komunikasi". ${ }^{3}$ Pernyataan Barnard tersebut bisa disimpulkan bahwa komunikasi memiliki peranan yang sangat penting dalam suatu organisasi. Untuk membedakan antara komunikasi organisasi dengan komunikasi yang ada di luar organisasi terletak pada struktur hierarki yang merupakan karakteristik dari setiap organisasi.

Adanya fenomena maupun studi sosial tentang pemimpinpemimpin Islam di Indonesia menunjukkan bahwa Kyai merupakan tokoh yang mempunyai posisi sentral dan strategis di lingkungan

2 Stewart L. Tubbs dan Sylvia Moss, Human Communication: Kontekskonteks Komunikasi, (Bandung: PT Remaja Rosdakarya, 2005), hlm. 168

3 Miftah Thoha, Perilaku Organisasi: Konsep Dasar dan Aplikasinya, (Jakarta: Rajawali Pers, 2014), hlm. 185

48 
EVALUASI, 4 (1), Maret 2020, ISSN 2580-3387 (print) |

ISSN 2615-2886 (online)

Homepage : http://e-journal.staima-alhikam.ac.id/index.php/evaluasi

DOI : : http://doi.org/10.32478/evaluasi.v4i1.355

Article type : Original Reseacrh Article

masyarakat. Dalam kajian sosiologi, ada fenomena kehidupan sosial yang diparalelkan dengan teori interaksionisme simbolik. Interaksionisme simbolik adalah teori yang mempelajari sifat interaksi dimana hal tersebut merupakan kegiatan sosial dinamis manusia. George Herbert Mead dan Herbert Blumer adalah tokoh yang mengembangkan teori ini. Dalam perspektif ini setidaknya ada beberapa premis yang dipahami, yaitu; makna simbol, diri (self), interaksi sosial, dan masyarakat. Dalam perspektif ini, individu bersifat aktif, reflektif, dan kreatif, menafsirkan, menampilkan perilaku yang rumit dan sulit diramalkan.

Teori di atas jika digunakan untuk menganalisis kepemimpinan Kyai di pondok pesantren menarik untuk dikaji, tentang simbol misalnya, kepemimpinan kolektif-kolegial dalam membangun efektifitas komunikasi organisasi terkadang hanya menggunakan simbol-simbol tertentu yang jika dijelaskan dapat menguak tabir apa arti sebenarnya dari simbol-simbol tersebut. Bisa jadi anggota organisasi pondok pesantren melaksanakan tugas-tugasnya dengan dasar pengabdian dan mendedikasikan diri mereka atas dasar komitmen dan ketulusan, atau mungkin mereka melaksanakan program-program pondok pesantren bukan atas dasar kesetiaan, dan ketulusan saja, akan tetapi karena mereka ada ketergantungan kepada Kyai yang diikuti (istinâd), baik ketergantungan terhadap status sosial ekonomi, atau bahkan mereka melakukan semua aktivitas-aktivitas atas dasar sebagaimana yang diungkapkan Weber, bahwa mereka tersebut melakukan tindakan-tindakan rasionalitas nilai (Wertrational).

Oleh karena itu representasi pondok pesantren besar yang tetap survive di tengah-tengah perubahan dan menarik untuk dikaji dalam penelitian ini adalah sebagai berikut:

Pertama, peneliti melakukan wawancara dengan salah satu pengurus PP Bahrul Ulum Tambakberas, Khumaidi Abdillah selaku anggota departemen humasy. PP Tambakberas merupakan salah satu pondok pesantren tertua dan terbesar di Jawa Timur yang hingga hari ini masih survive di tengah kecenderungan kuat sistem pendidikan formal. Secara struktural, PP Tambakberas berada di bawah naungan 
EVALUASI, 4 (1), Maret 2020, ISSN 2580-3387 (print) |

ISSN 2615-2886 (online)

Homepage : http://e-journal.staima-alhikam.ac.id/index.php/evaluasi

DOI : : http://doi.org/10.32478/evaluasi.v4i1.355

Article type : Original Reseacrh Article

Yayasan PP Bahrul Ulum. Yayasan ini berdiri sejak tahun 1966 melalui Akte Notaris nomor 03 tanggal 06 September 1966 dihadapan notaris Soembono Tjiptowidjojo dahulu wakil notaris di Mojokerto. PP Tambakberas diurus dan dikelola dibawah manajemen Yayasan PP Bahrul Ulum sedangkan untuk pengelolaan perguruan tinggi dibentuk Yayasan Pendidikan Tinggi Bahrul Ulum. Secara hierarki organisatoris kepengurusan tersebut terdiri dari: (1) Majelis Pengasuh/ Dewan Pembina: (2) Dewan Pengawas; (3) Pengurus Harian; dan (4) Pengurus Bidang/ Departemen. Hingga saat ini, sejak kepemimpinan kolektif-kolegial ini diterapkan, sudah mengalami dua periode kepemimpinan Majelis Pengasuh, yaitu: (1) (Almaghfurlah) KH.M. Sholeh Abdul Hamid, 1987 - 2006; (2) (Almaghfurlah) Drs. KH. Amanulloh Abdur Rochim 2007-2008; dan (3) KH. Moh. Hasib Wahab (2009 - Sekarang).

Kedua, peneliti melakukan wawancara dengan salah satu pengurus PP Denanyar, H. Jauharul Afif, Lc dan melakukan observasi sepintas. Nama pondok pesantren Mamba'ul Ma'arif, yang lebih dikenal dengan sebutan Pondok Denanyar, memang sudah tak asing lagi buat orang Indonesia - lebih-lebih bagi masyarakat Jawa Timur. Apalagi tak sedikit tokoh-tokoh yang berkaliber nasional, lahir dari pesantren ini. KH. M. Bishri Sansuri mendirikan pondok pesantren di tempat yang berjarak $2 \mathrm{Km}$ arah Barat kota Jombang dengan dorongan istrinya Nyai Hj. Noor Khodijah dan mertuanya KH. Hasbullah serta gurunya KH. Hasyim Asy'ari, pada tahun 1917. Saat ini jumlah santri PP Mamba'ul Ma'arif mencapai 1500 santri. Jika ditambah dengan yang ada di lembaga pendidikan formal, jumlahnya berkisar pada 4000 santri. Pasca wafatnya KH. M. Bishri syansuri (1980), maka pola kepemimpinan di pondok Pesantren Mamba'ul Ma'arif berubah menjadi kolektif-kolegial. Hal ini terwujud dengan penentuan segala kebijakan akan selalu lahir dari pemikiran yang kolektif melalui rapat atau musyawarah pengurus yayasan maupun para dewan pengasuh

Dari keterangan di atas kedua pondok pesantren ini menjadi menarik untuk diteliti karena kedua pesantren tersebut didirikan oleh para pendiri organisasi Islam terbesar di Indonesia yakni Nahdlatul 
EVALUASI, 4 (1), Maret 2020, ISSN 2580-3387 (print) |

ISSN 2615-2886 (online)

Homepage : http://e-journal.staima-alhikam.ac.id/index.php/evaluasi

DOI : : http://doi.org/10.32478/evaluasi.v4i1.355

Article type : Original Reseacrh Article

Ulama dan menjadikan nilai ahlu as-sunnah wa al-jama'ah sebagai pondasi dasar di pesantren, selain itu gaya kepemimpinan yang diterapkan hingga saat ini juga sama-sama menggunakan kepemimpinan kolektif-kolegial hanya saja bentuk dan struktur organisasinya memiliki sedikit perbedaan.

Model kepemimpinan kolektif-kolegial atau bentuk Yayasan (yang berisikan anggota keluarga) ini dinilai sebagai salah satu solusi strategis di pesantren, karena beban kiai/ pengasuh pesantren menjadi lebih ringan, karena ditangani bersama sesuai dengan tugas masingmasing. Kiai juga tidak terlalu menanggung beban moral tentang kelanjutan pesantren di masa depan. Namun demikian kolektifitas dan kolaborasi ini masih bersifat pasif, karena kolektivitas kepemimpinan di pondok pesantren tersebut terkadang masih lebih didominasi kiai sebagai pimpinan pesantren.

Perilaku kepemimpinan kolektif di pesantren yang direpresentasikan dari majlis kiai dapat diasumsikan sebagai perilaku kepemimpinan demokratis. Hal ini karena kiai tidak memimpin pesantren secara individual, melainkan memimpin dengan beberapa kiai secara kolektif. Seperti yang ditegaskan oleh Syarqawi Dhofir, bahwa kekuasaan kiai tidak terpusat pada satu figur kiai, melainkan ada dalam kepemimpinan kolektif, yang berwujud dewan pimpinan. ${ }^{4} \mathrm{Hal}$ ini relevan kiranya apabila konteks kepemimpinan kolektif di pesantren ini disandingkan dengan teori management system Rensis Likert dengan menggunakan prinsip dasar leadership continoum. Dari hasil risetnya, ia menemukan 4 perilaku kepemimpinan yaitu: ${ }^{5}$ (1) Sistem exploitative authoritative (otoriter dan memeras); (2) Sistem benevolent authoritative (otoriter yang baik).; (3) Sistem consultative (konsultasi); dan (4) Sistem participative (partisipasi).

Selanjutnya model komunikasi organisasi menggambarkan bagaimana jalannya proses komunikasi pada suatu organisasi. Proses

${ }^{4}$ Syarqawi Dhofir, Kekuasaan dan Otoritas Kiai dalam Pondok Pesantren, (Surabaya: UNESA, 2004), hlm. 22

${ }^{5}$ Rensis Likert, The Human Organization: Its Management and Value, (New York: McGraw-Hill, 1967) 
EVALUASI, 4 (1), Maret 2020, ISSN 2580-3387 (print) |

ISSN 2615-2886 (online)

Homepage : http://e-journal.staima-alhikam.ac.id/index.php/evaluasi

DOI : : http://doi.org/10.32478/evaluasi.v4i1.355

Article type : Original Reseacrh Article

komunikasi ini adalah proses timbal balik antara komunikator sebagai pengirim (sender) dan komunikan sebagai penerima pesan (receiver) sampai dapat menciptakan pengertian dan penerimaan yang sama, serta menghasilkan suatu tindakan yang sama untuk mencapai tujuan. Tahaptahap proses komunikasi dapat digambarkan ssebagai berikut: ${ }^{6}$

Gambar 2.2 Proses Komunikasi

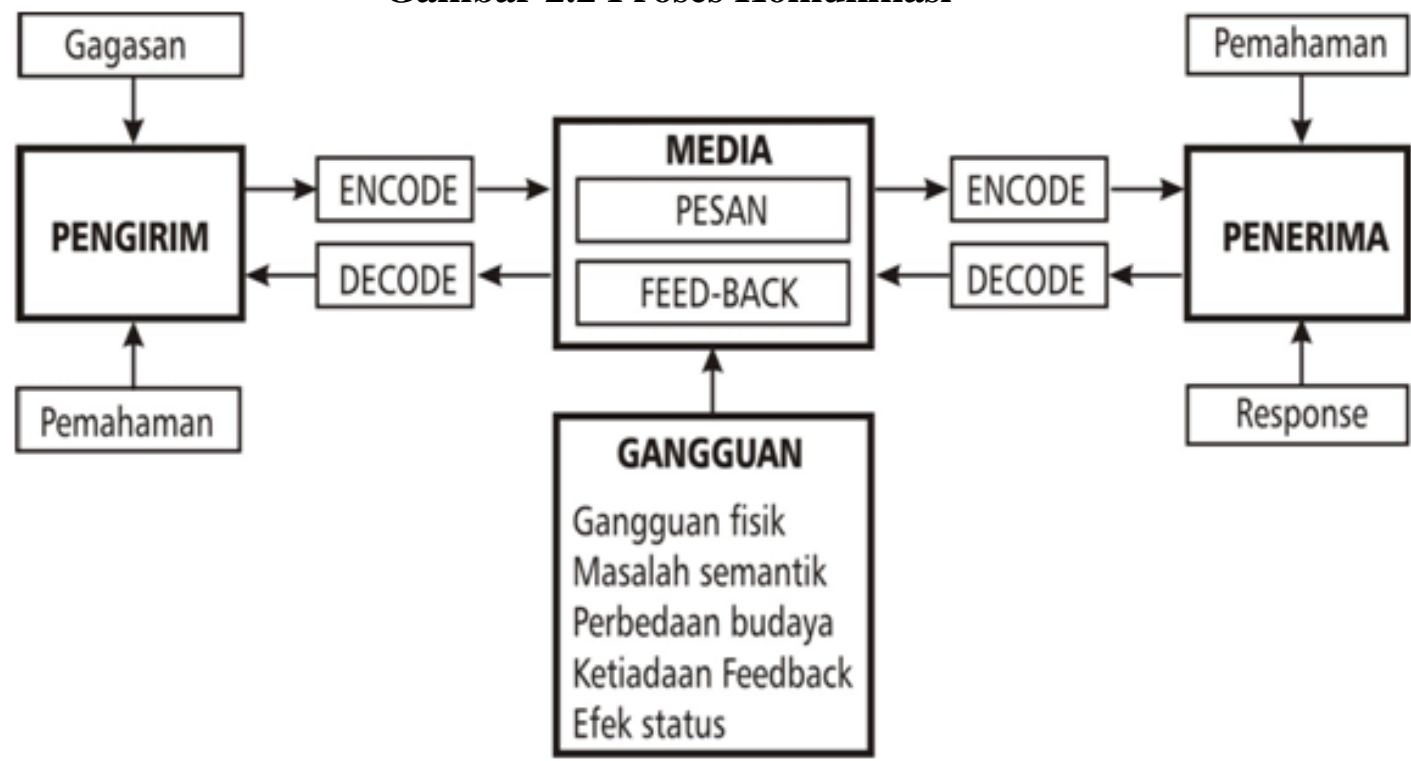

Berbagai model proses komunikasi yang diajukan oleh para ahli menggunakan beberapa istilah sebagai berikut, dimulai dari yang paling sederhana sampai pada yang paling rumit. Pertama model linear terdiri dari source - message - receiver, untuk sampainya message ke receiver ada channel, lalu dari receiver ada feedback. A menyampaikan pesan kepada B, A adalah Source, dan yang disampaikan itu disebut Message, sedangkan saluran yang digunakan disebut Channel, B sendiri disebut Receiver, kalau B memberikan tanggapan atas apa yang disampaikan A maka disebut Feedback. Model komunikasi sederhana ini meupakan

${ }^{6}$ U. Saefullah, Manajemen Pendidikan Islam, (Bandung: CV Pustaka Setia, 52 
EVALUASI, 4 (1), Maret 2020, ISSN 2580-3387 (print) |

ISSN 2615-2886 (online)

Homepage : http://e-journal.staima-alhikam.ac.id/index.php/evaluasi

DOI : : http://doi.org/10.32478/evaluasi.v4i1.355

Article type : Original Reseacrh Article

pengembangan dari S-R seperti diperkenalkan oleh John C. Zacharis dan Coleman C.Bender. ${ }^{7}$ Model ini sangat sederhana, namun ketika dalam praktik komunikasi ternyata sering dijumpai ada penerimaan pesan yang tidak seragam. Hal itu karena satu sama lain berbeda dalam memberikan makna pada pesan tersebut, sehingga banyak melahirkan berbagai model komunikasi lainnya.

Model kedua lebih luas lagi. Dalam istilah Baran, model ini disebut dengan model circular. Adapun istilah yang digunakan oleh Schramm adalah Encoder - Interpreter - Decoder - Message Encoder - Interpreter - Decoder. ${ }^{8}$ Mengambil contoh di atas menurut model kedua, A memiliki Encoder-Interpreter dan Decoder, demikian juga B. Message menurut model ini dimiliki oleh A ketika menyampaikan sesuatu sesuai dengan interpretasinya, lalu diterima oleh Decoder B sesuai interpretasinya, lalu B mengirimkan Massage ke A yang diterima oleh Decoder-nya dan dipahami oleh interpreternya.

Model ketiga menggambarkan komunikasi linear versi Shanon dan Weaver yang bekerja secara mekanik bermula dari SourceEncoder-Message- Decoder-Destination- kemudian Feedback. Source A melalui Encoder B mengirim pesan diterima oleh Decoder D sehingga sampai pada tujuan (sasaran), lalu sasaran memberikan feedback ke A. ${ }^{9}$ Model ini sangat mekanistik dan antara B dan D bisa melahirkan noise. Ketiga model tersebut mencoba menjelaskan banyaknya komponen yang terlibat dalam proses komunikasi.

Terkait dengan Teori Interaksi Simbolik, maka perlu kiranya mendefinisikan terlebih dahulu arti dari kata "interaksi" dan "simbolik". Menurut kamus komunikasi (Effendy. 1989: 184) definisi interaksi adalah proses saling mempengaruhi dalam bentuk perilaku atau

7 DedyMulyana, Ilmu Komunikasi Suatu Pengantar, (Bandung: Remaja Rosda Karya,2001) Cet.II, hlm, 133.

${ }^{8}$ Baran J. Stanley, Jerilyn S. Mclntyre, Timothy P. Meyer, Self Symbols and Society: An Introduction To Mass Communication, (London: Addison-Wesley Publishing Company, Inc, 1984), hlm.16

${ }^{9}$ Baran J. Stanley, Jerilyn S. Mclntyre, Timothy P. Meyer, Self Symbols and Society...... hlm.17 
EVALUASI, 4 (1), Maret 2020, ISSN 2580-3387 (print) |

ISSN 2615-2886 (online)

Homepage : http://e-journal.staima-alhikam.ac.id/index.php/evaluasi

DOI : : http://doi.org/10.32478/evaluasi.v4i1.355

Article type : Original Reseacrh Article

kegiatan di antara anggota-anggota masyarakat ${ }^{10}$, sedangkan definisi simbolik adalah bersifat melambangkan sesuatu. ${ }^{11}$

Istilah ini pertama kali diperkenalkan oleh Herbert Blumer dalam lingkup sosiologi, akan tetapi sebenarnya ide ini telah dikemukakan oleh George Herbert Mead (guru Blumer) yang kemudian dimodifikai oleh Blumer untuk tujuan tertentu. Definisi singkat dari ketiga ide dasar dari teori interaksionisme simbolik, antara lain: (1) Pikiran (mind), yaitu kemampuan untuk menggunakan simbol yang mempunyai makna sosial yang sama, di mana tiap individu harus mengembangkan pikiran mereka melalui interaksi dengan individu lain, (2) Diri (seIf), yaitu kemampuan untuk merefleksikan diri tiap individu dari penilaian sudut pandang atau pendapat orang lain, dan teori interaksionisme simbolik adalah salah satu cabang dalam teori sosiologi yang mengemukakan tentang diri sendiri (the self) dan dunia luarnya, dan (3) Masyarakat (society), yaitu jejaring hubungan sosial yang dibangun, diciptakan, dan dikonstruksikan oleh tiap individu di tengah masyarakat, dan tiap individu tersebut terlibat dalam perilaku yang mereka pilih secara aktif dan sukarela, yang pada akhirnya mengantarkan manusia dalam proses pengambilan peran di tengah masyarakatnya.

Dengan begitu, manusia merupakan aktor yang sadar dan reflektif, yang menyatukan obyek-obyek yang di ketahuinya melalui apa yang disebut Blumer sebagi self indication. Self indication adalah proses komunikasi yang sedang berjalan dimana individu mengetahui sesuatu, menilainya, memberinya makna dan memutuskan untuk bertindak berdasarkan makna itu. Proses self indication ini terjadi dalam konteks sosial dimana individu mencoba "mengantisipasi" tindakantindakan orang lain dan menyesuaikan tindakannya sebagaimana dia menafsirkan tindakan itu ${ }^{12}$

${ }^{10}$ Onong Uchjana Effendy, Kamus Komunikasi, (Bandung: Mandar Maju, 1989), hlm. 184

${ }^{11}$ Ibid., hlm. 352

12 Soeprapto, Interaksionisme Simbolik (Perspektif Sosiologi Modern), (Malang: Averroes Press, 2001), hlm. 122

54 
EVALUASI, 4 (1), Maret 2020, ISSN 2580-3387 (print) |

ISSN 2615-2886 (online)

Homepage : http://e-journal.staima-alhikam.ac.id/index.php/evaluasi

DOI : : http://doi.org/10.32478/evaluasi.v4i1.355

Article type : Original Reseacrh Article

Seperti yang telah diindikasikan sebelumnya bahwa ketika ingin mengaplikasikan suatu perspektif dalam sosiologi untuk menjelaskan fenomena keagamaan bukanlah sesuatu yang mudah, mengingat setiap perspektif memiliki karakteristik masing-masing. Tidak sedikit suatu penelitian yang diklaim bersifat sosiologis terjebak hanya mengupas masalah peran dan fungsi sosial agama sehingga terkesan abstrak dan dangkal. Padahal kalau mau lebih jauh melihat perspektif-perspektif yang ada dalam sosiologi maka akan terpampang berbagai alternatif untuk mengupas suatu fenomena keagamaan secara lebih mendalam.

Sebagai contoh, ketika ingin melakukan suatu penelitian tentang kepemimpinan kiai dalam kehidupan keseharian di pondok pesantren. Dengan menggunakan perspektif interaksionisme simbolik maka penggalian data yang akan dilakukan bisa merekonstruksi bagaimana sebenarnya kepemimpinan tersebut berjalan dan pengaruhnya bagi komunitas pesantren lainnya. Dari aspek simbol keagamaan, mungkin bisa dijabarkan lebih jauh berbagai macam simbol yang sering dijadikan media untuk menunjukkan kepemimpinan kiai. Tentu saja, pengertian simbol dalam perspektif ini tidak terbatas pada obyek benda saja, akan tetapi juga meliputi segala macam tindakan manusia.

Sehingga penelitian ini bertujuan khusus untuk menganalisis, dan menemukan hal-hal sebagai berikut: (1) Perilaku kepemimpinan kolektif-kolegial dan (2) Model komunikasi organisasi pesantren ditinjau dari teori interaksionisme simbolik; di PP Bahrul Ulum Tambakberas dan PP Mambaul Maarif Denanyar Jombang.

\section{METODE PENELITIAN}

Penelitian ini merupakan suatu penelitian yang menggunakan pendekatan kualitatif. Penelitian ini diharapkan dapat membangun suatu teori secara induktif dari abstraksi-abstraksi data yang dikumpulkan di lapangan berdasarkan temuan-temuan yang didapatkan. Pondok pesantren yang menjadi objek penelitian adalah PP Bahrul Ulum Tambakberas Jombang dan PP Mamba'ul Ma;arif Denanyar Jombang. Kedua pesantren tersebut merupakan pondok pesantren besar dan berusia sangat tua dan sejatinya masih ada hubungan keluarga karena 
EVALUASI, 4 (1), Maret 2020, ISSN 2580-3387 (print) |

ISSN 2615-2886 (online)

Homepage : http://e-journal.staima-alhikam.ac.id/index.php/evaluasi

DOI : : http://doi.org/10.32478/evaluasi.v4i1.355

Article type : Original Reseacrh Article

pendiri PP Mambaul Maarif Denanyar KH. Bisri Syansuri menikah dengan adik KH. Wahab Hasbullah (Pengasuh PP Bahrul Ulum Periode 2). Hanya saja ada sedikit perbedaan pada pengelolaan pondok pesantren serta keunggulan program masing-masing pesantren.

Jenis penelitian ini adalah fenomenologi dengan menggunakan rancangan interaksionisme simbolik. Interaksi (interaksionisme) simbolik merupakan salah satu di antara beberapa perspektif utama yang dikenal dalam ilmu-ilmu sosial, seperti sosiologi, psikologi, antropologi, dan komunikasi. Namun, belakangan bidang-bidang lain seperti pendidikan, politik, dan bidang kemasyarakatan lainnya mulai menggunakan perspektif ini dalam mengkaji topik-topik kajiannya. Sehingga dalam hal ini, peneliti berusaha untuk memahami subjek penelitiannya dari sudut pandang subjek itu sendiri dengan tidak mengabaikan dalam membuat penafsiran dan membuat skema konseptual. ${ }^{13}$

Untuk memperoleh data secara holistik dan integratif, serta memperhatikan relevansi data dengan fokus dan tujuan, maka dalam pengumpulan data penelitian ini peneliti memakai tiga teknik yang ditawarkan oleh Bagdan dan Biklen, yaitu: (1) wawancara mendalam (indept interview); (2) observasi partisipan (participant observation); dan (3) studi dokumentasi (study document). ${ }^{14}$ Ketiga teknik pengumpulan data tersebut akan dijelaskan dibawah ini:

Wawancara Mendalam (Indept Interview). Dalam penelitian ini teknik wawancara yang digunakan adalah wawancara tidak terstruktur (unstandardized interview) yang dilakukan tanpa menyusun suatu daftar pertanyaan yang ketat. Selanjutnya, wawancara yang tidak terstandar ini dikembangkan menjadi 3 teknik, yaitu: (a) wawancara tidak terstruktur (unstandardized passive interview) yang dapat

13 Nurul Ulfatin, Metode Penelitian Kualitatif di Bidang Pendidikan, (Malang: Bayumedia Publishing, 2013), hlm. 96

${ }^{14}$ Bogdan dan Biklen, Qualitative Research, hlm. 119-143 
EVALUASI, 4 (1), Maret 2020, ISSN 2580-3387 (print) |

ISSN 2615-2886 (online)

Homepage : http://e-journal.staima-alhikam.ac.id/index.php/evaluasi

DOI : : http://doi.org/10.32478/evaluasi.v4i1.355

Article type : Original Reseacrh Article

menghasilkan informasi "emic"15; (b) wawancara agak terstruktur (some what structured or active interview) yang dapat menghasilkan informasi "etic" 16; dan (c) wawancara samnbil lalu (casual interview).

Dalam memilih informan pertama, yang dipilih adalah informan yang memiliki pengetahuan khusus, informatif, dan dekat dengan situasi yang menjadi focus penelitian, di samping memiliki status tertentu. Misalnya ketua pondok pesantren dan pengasuhan diasumsikan memiliki banyak informasi tentang pondok pesantren dan model komunikasi organisasi di pondok pesantren, sedangkan kiai sebagai informan kunci diasumsikan memiliki banyak informasi tentang perilaku kepemimpinannya selama mengasuh pondok pesantren. Oleh karena itu, Kiai/ pengasuh pondok serta ketua dan wakil pondok pesantren dipilih sebagai informan pertama untuk diwawancarai. Berikut daftar informan yang akan peneliti jadikan sebagai key informant dalam penelitian ini:

Tabel 3.2 Daftar Informan

\begin{tabular}{|l|c|c|}
\hline No & Nama Informan pada Situs 1 & Nama Informan pada Situs 2 \\
\hline 1. & $\begin{array}{c}\text { KH. M. Hasib Wahab (Ketua } \\
\text { Majelis Pengasuh PP. Bahrul } \\
\text { Ulum) }\end{array}$ & $\begin{array}{c}\text { KH. Abdussalam Shohib } \\
\text { (Pengasuh PP Mambaul } \\
\text { Ma'arif) }\end{array}$ \\
\hline 2. & $\begin{array}{c}\text { KH. Abd. Nahir Fattah (Wakil } \\
\text { Ketua Majelis Pengasuh PP. } \\
\text { Bahrul Ulum) }\end{array}$ & $\begin{array}{c}\text { Nyai Hj. Shohib Bisri (Wakil } \\
\text { Pengasuh PP Mambaul Ma'arif) }\end{array}$ \\
\hline 3. & $\begin{array}{c}\text { KH. M. Irfan Sholeh, M.MPd } \\
\text { (Ketua Umum Yayasan PP. } \\
\text { Bahrul Ulum) }\end{array}$ & $\begin{array}{c}\text { Nyai Hj. Hamidah Ahmad } \\
\text { (Ketua Yayasan PP. Mambaul } \\
\text { Ma'arif) }\end{array}$ \\
\hline 4. & $\begin{array}{c}\text { Drs. KH. Abd. Choliq, S.H, } \\
\text { M.Si (Sekretaris Umum } \\
\text { Yayasan PP. Bahrul Ulum) }\end{array}$ & $\begin{array}{c}\text { Drs. H. A. Halim Iskandar } \\
\text { (Wakil Ketua Yayasan PP. } \\
\text { Mamba'ul Ma'arif) }\end{array}$ \\
\hline
\end{tabular}

15 Emic adalah informasi dari responden yang menggambarkan pandangan dunia dari segi perspektifnya, menurut pikiran dan perasaannya. Baca S. Nasution, Metode Penelitian Naturalistik, hlm. 71

${ }^{16}$ Etic adalah informasi dari responden yang kemudian oleh peniliti diolah, ditafsirkan, dianalisis, menurut metode, teori, teknik dan pandangan peneliti sendiri 
EVALUASI, 4 (1), Maret 2020, ISSN 2580-3387 (print) |

ISSN 2615-2886 (online)

Homepage : http://e-journal.staima-alhikam.ac.id/index.php/evaluasi

DOI : : http://doi.org/10.32478/evaluasi.v4i1.355

Article type : Original Reseacrh Article

Observasi Partisipan (Participant Observation). Dalam penelitian ini, peneliti juga melakukan observasi dalam tiga tahap, dimulai dari observasi deskriptif (descriptive observation) secara luas dengan menggambarkan secara umum situasi sosial yang terjadi di ketiga pondok pesantren. Tahap berikutnya dilakukan observasi terfokus (focused observation) untuk menemukan kategori-kategori, seperti perilaku kepemimpinan kolektif-kolegial dan model komunikasi organisasi di pesantren. Tahap akhir setelah dilakukan analisis dan observasi berulang-ulang, diadakan penyempitan lagi dengan melakukan observasi selektif (selective observation) dengan mencari perbedaan di antara kategori-kategori, misalnya struktur organisasi ketiga pondok pesantren. Semua hasil pengamatan dicatat sebagai rekaman pengamatan lapangan (field note), yang selanjutnya dilakukan refleksi.

Studi Dokumentasi (Study Document). Dokumentasi dalam penelitian ini digunakan untuk mengumpulkan data-data yang mendukung untuk memahami dan menganalisis kepemimpinan kolektif kiai dalam membangun komunikasi organisasi di pesantren. Sebagai alat pengumpul data adalah flashdisk, camera digital dan lembar catatan lapangan.

Selanjutnya analisis data adalah proses pelacakan dan pengaturan secara sistemik transkrip wawancara, catatan lapangan, dan bahan-bahan lain yang dikumpulkan untuk meningkatkan pemahaman terhadap bahan-bahan lain yang dikumpulkan untuk meningkatkan pemahaman terhadap bahan-bahan tersebut agar dapat dipresentasikan temuannya kepada orang lain. Dalam penelitian kualitatif, data dianalisis pada saat pengumpulan data dan setelah selesai pengumpulan data. ${ }^{17}$

Untuk itu dalam penelitian ini, peneliti menggunakan model analisis data yang digagas oleh Spradley: yang terdiri dari 4 cara, yaitu: (1) analisis domain; (2) analisis taksonomi; (3) analisis komponensial;

17 Ahmad Sonhadji, dkk., Penelitian Kualitatif dalam Bidang Ilmu-ilmu Sosial dan Keagamaan, (Malang: Kalimashada Press, 1994), hlm. 77 58 
EVALUASI, 4 (1), Maret 2020, ISSN 2580-3387 (print) |

ISSN 2615-2886 (online)

Homepage : http://e-journal.staima-alhikam.ac.id/index.php/evaluasi

DOI : : http://doi.org/10.32478/evaluasi.v4i1.355

Article type : Original Reseacrh Article

dan (4) analisis tema kultural. ${ }^{18}$ Namun dalam proses analisis data yang akan dilakukan peneliti dalam melakukan penelitian nantinya hanya meliputi analisis domain. Analisis domain adalah analisis yang digunakan untuk mendapatkan gambaran yang bersifat umum dan relative menyeluruh terhadap fokus studi. Artinya analisis hasil studi hanya ditargetkan untuk memperoleh gambaran seutuhnya dari perilaku kepemimpinan kolektif-kolegial di pesantren dan harus dirinci unsurunsurnya secara detail.

\section{PEMBAHASAN DAN HASIL PENELITIAN}

Perspektif kepemimpinan kolektif-kolegial yang diterapkan di pondok pesantren adalah kepemimpinan bersama para masyâyîkh (dewan kiai sepuh) dari garis kekerabatan (kinship/ dzurriyyah) dalam suatu organisasi di pondok pesantren. Kepemimpinan kolektif-kolegial ini mendukung terhadap teori kepemimpinan yang relevan di masa modern ini. Kepemimpinan sebagai sebuah perilaku dari individu yang memimpin aktivitas-aktivitas suatu kelompok ke suatu tujuan (shared goal) yang ingin dicapai bersama (collective). Lebih jelas lagi, Abu Sinn mendefinisikan kepemimpinan sebagai sebuah sistem dan bukanlah unsur tunggal yang memberikan pengaruh kepada orang lain, melainkan ia juga dipengaruhi oleh pendapat masyarakat, karena seorang pemimpin adalah bagian dari anggota masyarakat (jamâ'ah) yang saling berkontribusi, bertukar pendapat dan pengalaman, serta bersama-sama berusaha mewujudkan tujuan kolektif. ${ }^{19}$

Perspektif kepemimpinan kolektif-kolegial di kedua pesantren sebagaimana hasil penelitian ini, kiranya telah menjawab kekhawatiran masyarakat terhadap sistem kepemimpinan pesantren selama ini, sebagaimana pandangan A'la, bahwa selama ini manajemen (kepemimpinan) pesantren (meski tidak semua), dikelola seadanya

${ }^{18}$ Arief Furchan \& Agus Maimun, Studi Tokoh: hlm. 64

${ }^{19}$ Abu Sinn, Al-Idârah fì al-Islâm, (terj. Dimyauddin Juwaini), Jakarta: Radja Grafindo Persada, 2006 
EVALUASI, 4 (1), Maret 2020, ISSN 2580-3387 (print) |

ISSN 2615-2886 (online)

Homepage : http://e-journal.staima-alhikam.ac.id/index.php/evaluasi

DOI : : http://doi.org/10.32478/evaluasi.v4i1.355

Article type : Original Reseacrh Article

dengan kesan menonjol pada penanganan individual dan bernuansa kharismatik. ${ }^{20}$

Perilaku kepemimpinan kolektif-kolegial di pondok pesantren Tambakberas dan pondok pesantren Denanyar kian meyakinkan peneliti terhadap transformasi yang telah diperankan kiai sebagai bentuk perubahan (silent revolution) yang diyakini sebagai pengaruh spirit keagamaan. Hal ini telah diprediksikan Gus Dur bahwa pada relasi sosio kultural kiai dan masyarakat terdapat relasi-peran kreatif kiai sebagai pelopor perubahan sosial (agent of change). ${ }^{21}$ Dengan kapasitasnya, kiai mampu menawarkan agenda perubahan yang dianggapnya sesuai dengan kebutuhan nyata masyarakat yang dipimpinnya. Perkembangan peran sosial kiai dalam konteks pesantren secara kualitatif saat ini, merupakan bagian tradisi, budaya, dan perilaku para pemimpinnya untuk mempertahankan hak hidup kumunitasnya yang ditempa dengan spirit keagamaan yang dahsyat.

Pada Pondok Pesantren Bahrul Ulum Tambak Beras Jombang dan Pondok Pesantren Mambaul Ma'arif Denanyar Jombang terdapat majelis pengasuh dalam struktur organisasi yang secara fungsional adalah untuk pembinaan terhadap pengurus harian. Majelis pengasuh ini mempunyai tugas-tugas utama, yaitu; (a) menyusun Garis-Garis Besar Kebijakan (GBK) pesantren dan yayasan, (b) meningkatkan koordinasi, konsolidasi, dan kerja sama, baik secara internal maupun eksternal pesantren, (c) mengambil kebijakan, (d) mengontrol pelaksanaan program dan kebijakan, serta (e) membina Sumber Daya Manusia (SDM) pesantren secara integral.

Sedangkan kedudukan dewan pengawas sebagai expetio dari lembaga pertimbangan pesantren. Sebagai badan pertimbangan dewan pengawas mempunyai tugas: (a) sebagai lembaga pengawasan, (b) sebagai lembaga konsultasi biro-biro pesantren, (c) sebagai bagian dari pengurus yayasan, (d) menyampaikan saran-saran dan sumbangan

20 Abd. A'la, Pembaruan Pesantren, Yogyakarta, Pustaka Pesantren,2006, hlm. 75

21 Abdurrahman Wahid, "Kata Pengantar" dalam Horikoshi, Kiai dan Perubahan Sosial, hlm. 32

60 
EVALUASI, 4 (1), Maret 2020, ISSN 2580-3387 (print) |

ISSN 2615-2886 (online)

Homepage : http://e-journal.staima-alhikam.ac.id/index.php/evaluasi

DOI : : http://doi.org/10.32478/evaluasi.v4i1.355

Article type : Original Reseacrh Article

pemikiran guna kepentingan penyusunan rencana program kerja dan Anggaran Pendapatan Belanja Pesantren (APBP), (e) melaksanakan tugas-tugasnya sesuai dengan ketentuan yang berlaku, dan (f) menyusun Rancangan Anggaran Pendapatan dan Belanja Pesantren (RAPBP) dan program kerja tahunan. Posisi dewan pengawas inilah yang tidak terdapat pada Pondok Pesantren Mambaul Ma''arif Denanyar Jombang.

Selanjutnya untuk pengurus harian baik di PPBU maupun di PPMA mempunyai tugas; (a) menyusun program kerja pengurus untuk masa bakti empat tahun di PPBU dan lima tahun di PPMA, (b) menyusun RAPBP dalam setiap tahun, (c) melaksanakan program kerja yang telah disahkan oleh majelis pengasuh, (d) menjatah dana pembiayaan kebutuhan dan keperluan tugas sesuai dengan alokasi APBP, (e) berhak mengambil kebijakan dalam melaksanakan tugasnya sepanjang tidak bertentangan dengan program kerja pesantren, (f) melaporkan pelaksanaan program kerja dan realisasi APB-PPS kepada majelis pengasuh serta mengajukan rencana program kerja tahunan dan RAPBP dalam setiap akhir tahun, dan (g) menandatangani surat-surat yang dialamatkan keluar dan ke dalam pesantren sesuai dengan tugas dan bidang masing-masing pengurus harian.

Berdasarkan pernyataan tersebut, dapat ditafsirkan bahwa fungsi masingmasing lembaga di pesantren yang dikelola dengan kepemimpinan kolektif-kolegial berjalan lebih dinamis dan fungsional sesuai dengan pembagian tugas yang telah ditetapkan dalam perencanaan secara administratif. Pembagian tugas yang jelas dan terarah sebagaimana dalam kepemimpinan kolektif-kolegial di atas, maka pondok pesantren dalam penelitian ini telah menganut sistem manajemen perencanaan terbuka. Salah satu ciri sistem perencanaan terbuka adalah organisasi memiliki diferensiasi atau spesialisasispesialisasi, di mana dalam organisasi pendidikan ada bagian kepengurusan, bagian pengajaran, dan bagian kepegawaian. Masingmasing bagian ini masih dapat dipecah menjadi bagian-bagian unit yang lebih kecil. 
EVALUASI, 4 (1), Maret 2020, ISSN 2580-3387 (print) |

ISSN 2615-2886 (online)

Homepage : http://e-journal.staima-alhikam.ac.id/index.php/evaluasi

DOI : : http://doi.org/10.32478/evaluasi.v4i1.355

Article type : Original Reseacrh Article

Perilaku kepemimpinan kolektif-kolegial di pesantren yang direpresentasikan dari majelis pengasuh dapat diasumsikan sebagai perilaku kepemimpinan demokratis. Hal ini karena kiai tidak memimpin pesantren secara individual, melainkan memimpin dengan beberapa kiai lainnya secara kolektif. Hal ini, seperti ditegaskan Syarqawi Dhofir, bahwa kekuasaan kiai tidak terpusat pada satu figur kiai, melainkan ada dalam kepemimpinan kolektif, yang berwujud dewan pimpinan. ${ }^{22}$ Relevan kiranya jika hasil penelitian ini disandingkan dengan hasil penelitian Rensis Likert menunjukkan bahwa perilaku kepemimpin yang berhasil dan efektif apabila pemimpin itu bergaya participative management yang menekankan pada orientasi bawahan dan komunikasi serta dalam organisasi, berpola hubungan yang mendukung (supportive relationship). ${ }^{23}$ Dalam konteks ini Likert merancang empat sistem kepemimpinan dalam manajemen:

1. Sistem exploitative authoritative (otoriter dan memeras). Karakter dari sistem ini adalah: pemimpin membuat keputusan dan memerintah bawahannya untuk melaksanakan; sekaligus menentukan standar hasil kerja dan cara pelaksanaannya; kegagalan pencapaian hasil yang ditetapkan mendapat ancaman dan hukuman; pemimpin menaruh kepercayaan kecil sekali terhadap bawahan dan sebaliknya bawahan merasa jauh dan takut sekali dengan atasan.

2. Sistem benevolen authoritative (otoriter yang baik), Karakteristik dari sistem ini adalah: pemimpin masih menentukan perintah, tetapi bawahannya mempunyai kebebasan untuk memberi tanggapan terhadap perintahnya; bawahan diberi kesempatan untuk melaksanakan tugasnya dalam batas-batas yang telah ditetapkan secara rinci sesuai dengan prosedur; bawahan yang telah mencapai sasaran produksi yang ditetapkan akan diberi hadiah dan penghargaan.

3. Sistem consultative (konsultasi). Karakteristik dari sistem ini adalah: pemimpin menetapkan sasaran tugas dan memberikan

${ }^{22}$ Syarqawi Dhofir, Kekuasaan dan Otoritas Kiai dalam Pondok Pesantren (Surabaya: UNESA, 2004), hlm. 22

${ }^{23}$ Husaini, Manajemen, Teori, Praktik, hlm. 268.

62 
EVALUASI, 4 (1), Maret 2020, ISSN 2580-3387 (print) |

ISSN 2615-2886 (online)

Homepage : http://e-journal.staima-alhikam.ac.id/index.php/evaluasi

DOI : : http://doi.org/10.32478/evaluasi.v4i1.355

Article type : Original Reseacrh Article

perintahnya setelah mendiskusikan hal tersebut dengan bawahannya; bawahan dapat membuat keputusan sendiri mengenai pelaksanaan tugasnya, tetapi keputusan penting dibuat oleh pemimpin tingkat atas; penghargaan dan ancaman/hukuman digunakan sebagai motivasi terhadap bawahannya; bawahan merasa bebas untuk mendiskusikan hal yang berkaitan dengan pekerjaannya dengan pemimpin; dan pemimpin merasa bahwa bawahan dapat dipercaya untuk melaksanakan tugasnya dengan baik.

4. Sistem participative (partisipasi). Karakteristik dari sistem ini adalah: sasaran tugas dan keputusan yang berhubungan dengan pekerjaan dibuat oleh kelompok; jika pemimpin mengambil keputusan maka keputusan itu diambil setelah memperhatikan pendapat kelompok; motivasi bawahan tidak saja berupa penghargaan ekonomis, tetapi juga berupa suatu upaya agar bawahannya merasakan bagaimana pentingnya mereka serta harga dirinya sebagai manusia yang bekerja; dan hubungan antara pemimpin dan bawahan terbuka, bersahabat, dan saling percaya.

Lebih lanjut Likert menyimpulkan bahwa penerapan exploitative authoritative dan benevolen authoritative akan menghasilkan produktivitas kerja rendah, sedangkan penerapan consultative dan partisipative akan menghasilkan produktivitas kerja yang tinggi. Sehingga jika dilihat dari hasil penelitian yang telah dipaparkan di Bab IV maka dapat diketahui jika perilaku kepemimpinan kolektif-kolegial di pondok pesantren Bahrul Ulum Tambakberas Jombang adalah kepemimpinan kolektif-kolegial yang partisipatif-demokratis, hal ini karena adanya kepercayaan (trust) atas wewenang dan tugas yang diberikan oleh majlis kiai, serta adanya saling berkaitan (connection) antara majlis kiai sebagai lembaga tertinggi, majlis a'wân sebagai lembaga pertimbangan, pengurus harian sebagai pelaksana kebijakan, dan pengurus yayasan sebagai pengelola aset pesantren. Sedangkan untuk kepemimpinan kolektif-kolegial di Pondok Pesantren Mambaul Ma'arif Denanyar Jombang adalah kepemimpinan kolektif-kolegial yang demokratis-konsultatif. Perilaku ini terjadi adanya dominasi kekuasaan dari majelis pengasuh atas kewenangan yang diberikan 
EVALUASI, 4 (1), Maret 2020, ISSN 2580-3387 (print) |

ISSN 2615-2886 (online)

Homepage : http://e-journal.staima-alhikam.ac.id/index.php/evaluasi

DOI : : http://doi.org/10.32478/evaluasi.v4i1.355

Article type : Original Reseacrh Article

kepada pengurus harian sehingga kreativitas pengurus harian terbatasi oleh perilaku dan tradisi-budaya kepesantrenan, serta tidak adanya lembaga pertimbangan yang khusus.

Kemudian dalam suatu organisasi sangat dibutuhkan adanya komunikasi organisasi yang mampu mengembangkan sikap anggota untukmerubah pola pikir dan pola perilakunya sehingga sejalan dengan apa yangmenjadi tujuan dari organisasi tersebut. Redding dan Sanborn dalam Arni Muhammad mengatakan bahwa komunikasi organisasi adalah pengiriman dan penerimaan informasi dalam organisasi yang kompleks. ${ }^{24}$ Sedangkan Zelko dan Dance mengatakan bahwa komunikasi organisasi adalah suatu system yang saling bergantung yang mencakup komunikasi internal dan komunikasi eksternal. ${ }^{25}$ Dari hasil penelitian terlihat bahwa model komunikasi di kedua pondok pesantren tersebut terjalin dengan efektif baik internal maupun eksternal. Taktkala komunikasi internal mereka menggabungkan dua model komunikasi yaitu updown communication dan buttom-up communication, sedangkan untuk komunikasi eksternal lebih pada pendekatan perilaku atau pendekatan social.

Model komunikasi organisasi baik di pondok pesantren Tambakberas maupun pondok pesantren Denanyar terpola dengan baik. Sikap tawaddu' dan tunduk para pengurus terhadap majelis pengasuh tetap disandarkan pada rasa hormat pada seorang yang alim serta ajaran agama, bahwa kiai sepuh adalah seorang yang alim dan pewaris Rasulallah SAW dalam membawa pesan-pesan agama, karena itu harus dijunjung tinggi dan ditaati. Dan keyakinan adanya barakah kiai selalu menjadi nafas dalam setiap pengelolaan pondok pesantren, bahwa semakin berkembang pesat pondok pesantren bukan tidak lain karena barokah dari para kiai-kiai sepuh terdahulu maupun yang ada saat ini.

Demikian juga model komunikasi yang dibangun antara kiai/pengasuh, ustadz, dan pengurus berlangsung dalam suasana kekeluargaan dan akrab. Karena kiai merasa bahwa sebagai manusia biasa tidak perlu adanya sekat atau jarak yang membuat para pengurus

${ }^{24}$ Arni Muhammad, Komunikasi Organisasi, Bumi Aksara, 2005, hal. 65

${ }^{25}$ Arni Muhammad, Komunikasi Organisasi, Bumi Aksara, 2005, hal 66 
EVALUASI, 4 (1), Maret 2020, ISSN 2580-3387 (print) |

ISSN 2615-2886 (online)

Homepage : http://e-journal.staima-alhikam.ac.id/index.php/evaluasi

DOI : : http://doi.org/10.32478/evaluasi.v4i1.355

Article type : Original Reseacrh Article

tambah menjauh dari kiainya, yang pada akhirnya bisa berdampak pada terputusnya komunikasi di antara kiai dengan para pengurus pondok pesantren. Jadi, sikap di atas semata-mata memang tidak hanya disebabkan pada ajaran agama saja namun sikap kekeluargaan dan keteladanan seorang kiai merupakan penentu keberlangsungan organisasi pondok pesantren.

Model komunkasi organisasi yang diterapkan di kedua pondok pesantren di atas senada dengan teori interaksionisme simbolik yang diungkapkan Ralph Larossa dan Donald C. Deities dalam West-Turner bahwa, interaksionisme simbolik pada intinya menjelaskan tentang bagaimana manusia, bersama dengan orang lain, menciptakan dunia simbolik dan bagaimana cara dunia membentuk perilaku manusia. lnteraksi simbolik ada karena ide-ide dasar dalam membentuk makna yang berasal dari pikiran manusia (mind) mengenai diri (self), dan hubungannya di tengah interaksi sosial, dan tujuan bertujuan akhir untuk memediasi, serta menginterpretasi maka di tengah masyarakat (society) di mana individu tersebut menetap. Seperti yang dicatat oleh Douglas dalam Ardianto, makna itu berasal dari interaksi, dan tidak ada cara lain untuk membentuk makna, selain dengan membangun hubungan dengan individu lain melalui interaksi dan komunikasi.

Oleh karena itu setiap organisasi tidak dapat meninggalkan komunikasi organisasi, dengan komunikasi organisasi semua elemen dalam organisasi terintegrasi ke dalam di mana integrasi ini akan memperkuat organisasi untuk menjaga keberlangsungan dalam mencapai tujuan. Komunikasi organisasi bukan hanya sekadar alat untuk mencapai tujuan, tetapi lebih dari itu, komunikasi organisasi merupakan suatu proses yang memunculkan adanya suatu makna yang dipahami secara bersama dan menjadi pola pikir dan pola perilaku yang sama dari anggota organisasi tersebut. Tanpa adanya pemaknaan akan tujuan organisasi, maka tujuan organisasi hanya merupakan slogan yang tidak berarti sama sekali. 
EVALUASI, 4 (1), Maret 2020, ISSN 2580-3387 (print) |

ISSN 2615-2886 (online)

Homepage : http://e-journal.staima-alhikam.ac.id/index.php/evaluasi

DOI : : http://doi.org/10.32478/evaluasi.v4i1.355

Article type : Original Reseacrh Article

\section{KESIMPULAN \& SARAN}

Dari berbagai pemaparan data dan hasil analisis di atas ada beberapa hal yang dapat peneliti simpulkan yaitu sebagai berikut:

1. Kepemimpinan kolektif-kolegial sangat cocok untuk diterapkan di pondok pesantren terlebih yang sudah berbentuk yayasan dan termasuk pondok yang besar. Adanya majelis pengasuh yang terdiri dari kiai sepuh sebagaipusat kepemimpinan kolektif di pesantren mempunyai peran-peran strategis dalam proses pengembangan organisasi kepesantrenan dan lembaga pendidikan yang lebih dinamis dan efektif melalui pelibatan semua unsur stakeholders pesantren, yaitu; majelis pengasuh sebagai brand manager, dewan pengawas sebagai auditor internal serta pengurus harian sebagai penerima delegasi (staffing) yang dibantu oleh kepala unit program pendidikan dan kepesantrenan. Adapun dua model kepemimpinan kolektif-kolegial di pesantren sebagai model kecenderungan dewasa ini di antaranya adalah: (1) partisipatif-demokratis, suatu sistem kepemimpinan yang kewenangannya berasal dari majelis pengasuh yang terdiri dari dewan kiai sepuh kepada pengurus harian, dan pengurus harian mempunyai kebijakan penuh atas kepercayaan yang diberikan dan dilaksanakan secara delegatif; sedangkan (2) partisipatif-konsultatif, adalah suatu sistem kepemimpinan yang kewenangannya berasal dari majelis pengasuh kepada pengurus harian, dan pengurus harian mempunyai kebijakan terbatas yang selalu harus dikonsultasikan kepada dewan kiai sepuh.

2. Dalam suatu organisasi sangat dibutuhkan adanya komunikasi organisasi yang mampu mengembangkan sikap anggota untukmerubah pola pikir dan pola perilakunya sehingga sejalan dengan apa yangmenjadi tujuan dari organisasi tersebut. Pada pondok pesantren sekalipun komunikasi internal dan eksternal juga dibutuhkan, dimana komunikasi internal menunjuk pada komunikasi yang terjadi dalam organisasi itu sendiri dan komunikasi eksternal yang menunjuk pada komunikasi antara organisasi dengan lingkungan luarnya. Ada dua model komunikasi organisasi yaitu, Komunikasi yang bersifat "top-down" hanya 
EVALUASI, 4 (1), Maret 2020, ISSN 2580-3387 (print) |

ISSN 2615-2886 (online)

Homepage : http://e-journal.staima-alhikam.ac.id/index.php/evaluasi

DOI : : http://doi.org/10.32478/evaluasi.v4i1.355

Article type : Original Reseacrh Article

memberikan instruksi-instruksi yang memerlukan pengembangan lebih lanjut, sedangkan para pengurus hanya melakukan apa yang digariskan oleh atasannya. Kemudian komunikasi yang bersifat "buttom-up" dimana dari bawahan memberikan feed back atas instruksi yang diberikan oleh atasannya sehingga tidak muncul kesalahpahaman. Oleh karena itu pada pondok pesantren menggunakan kedua model komunikasi tersebut karena lebih menekankan nilai-nilai kekeluargaan.

Adapun saran dan rekomendasi yang ingin penulis sampaikan yaitu:

1. Para peneliti yang berkait dengan tema kepemimpinan di pesantren hendaknya memperkaya pemikirannya dengan menggali persoalanpersoalan yang berkembang di pesantren, mencermati dinamika perspektif kepemimpinan pesantren yang lebih variatif dan unik.

2. para pemerhati pendidikan Islam, hendaknya semakin yakin danmenyadari bahwa pesantren tidaklah selamanya berada dalam bayang-bayang satu kiai (patronase kekiaian) yang selama ini dipersepsi sebagai sumber satu-satunya pemimpin berperilaku otoritarian. Dari hasil penelitian ini, para kiai telah membuka kran demokrasi melalui sistem musyawarah, mediasi dan pelibatan kiai dan para nyai yang lain dalam mengambil kebijakan, pengendalian konflik, dan pembangunan tim.

3. para kiai di pesantren hendaknya semakin menyadari bahwa sejarah pesantren tumbuh dan berkembang berdasarkan kebutuhan masyarakat, sehingga pengembangan pesantren di masa-masa mendatang harus dikembalikan atas dasar kebutuhan masyarakat dengan memberikan peluang dan kesempatan kepada masyarakat (stakeholder) untuk berpartisipasi dan berkontribusi sesuai dengan kemampuan dan kebutuhan pesantren serta masyarakat. 
EVALUASI, 4 (1), Maret 2020, ISSN 2580-3387 (print) |

ISSN 2615-2886 (online)

Homepage : http://e-journal.staima-alhikam.ac.id/index.php/evaluasi

DOI : : http://doi.org/10.32478/evaluasi.v4i1.355

Article type : Original Reseacrh Article

\section{DAFTAR PUSTAKA}

A'la, Abd. 2006. Pembaruan Pesantren. Yogyakarta: Pustaka Pesantren Dhofir, Syarqawi. 2004. Kekuasaan dan Otoritas Kiai dalam Pondok Pesantren. Surabaya: UNESA

Effendy, Onong Uchjana. 2011. Ilmu Komunikasi: Teori dan Praktek. Bandung: PT Remaja Rosdakarya

Likert, Rensis. 1967. The Human Organization: Its Management and Value. New York: McGraw-Hill

Lincoln, Yvonna S and Egon G. Guba. 1985. Naturalistic Inquiry. Beverly Hills, California: Sage Publication

Muhammad, Arni. 2005. Komunikasi Organisasi. Bumi Aksara

Mulyana, Dedy. 2001. Ilmu Komunikasi Suatu Pengantar. Bandung:

Remaja Rosda Karya

Robbins, Stephen P. 2003. Organizational Behavior. Mexico: Pentice Hall

Sinn, Abu. 2006. Al-Idârah fì al-Islâm, (terj. Dimyauddin Juwaini). Jakarta: Radja Grafindo Persada

Soeprapto. 2001. Interaksionisme Simbolik (Perspektif Sosiologi Modern). Malang: Averroes Press

Stanley, Baran J., Jerilyn S. Mclntyre, Timothy P. Meyer. 1984. Self Symbols and Society: An Introduction To Mass Communication. London: Addison-Wesley Publishing Company, Inc

Sugiyono. 2009. Metode Penelitian Pendidikan Pendekatan Kuantitatif, Kualitatif dan $R \& D$. Bandung: Alfabeta

Thoha, Miftah. 2014. Perilaku Organisasi: Konsep Dasar dan Aplikasinya. Jakarta: Rajawali Pers

Tubbs, Stewart L. dan Sylvia Moss. 2005. Human Communication: Konteks-konteks Komunikasi. Bandung: PT Remaja Rosdakarya

U. Saefullah. 2012. Manajemen Pendidikan Islam. Bandung: CV Pustaka Setia

Ulfatin, Nurul. 2013. Metode Penelitian Kualitatif di Bidang Pendidikan. Malang: Bayumedia Publishing 
EVALUASI, 4 (1), Maret 2020, ISSN 2580-3387 (print) |

ISSN 2615-2886 (online)

Homepage : http://e-journal.staima-alhikam.ac.id/index.php/evaluasi

DOI $\quad:$ http://doi.org/10.32478/evaluasi.v4i1.355

Article type : Original Reseacrh Article

Wahid, Abdurrahman. "Kata Pengantar" dalam Horikoshi. Kiai dan Perubahan Sosial

Yin, Robert K. 1996. Case Study Research; Design and Methods, Trj: M. Djauzi Mudzakir. Studi Kasus; Desain dan Metode. Jakarta: PT. Raja Grafindo Persada 